\title{
Developing Big Book as a Media for Teaching English at Sixth Grade Students of Elementary School at SD Lab Undiksha Singaraja
}

\author{
Ni Wayan Surya Mahayanti1,*, Ni Luh Putu Mira Suantari² \\ ${ }^{1}$ English Education Department, Universitas Pendidikan Ganesha \\ 2 English Education Department, Universitas Pendidikan Ganesha
}

\begin{abstract}
Abstrak
This research aimed to (1) develop character based big book as a media for teaching English at sixth grade students at SD Lab UNDIKSHA Singaraja, and (2) find out the quality of character based big book developed. The subject of this research was thirtytwo students of sixth grade students of elementary school at SD Lab UNDIKSHA Singaraja. The data of this research were obtained by using observation sheet, interview guide, item of questionnaire, checklist, rubric, and notes. This research was R \& D (research and development) which followed several procedures based on Sugiyono model namely identifying potency and problem, collecting data, designing product, validating design product, revising design product, trying-out product, and revising product. The result of this research showed that there were five kinds of character based big book developed with the theme seasons, tourism, direction, airport, and transportation. Each big book consisted of fourteen up to fifteen pages and inserted character education in its story. For the quality of the media, it was found that the character based big book developed was categorized as excellent media. Thus, it was proper to be used as a media for teaching English at sixth grade students.
\end{abstract}

\author{
Keywords: \\ Big Book; \\ Character Education; \\ Teaching English for \\ Young Learners
}

\section{Introduction}

Teaching English for young learners becomes common issue in this globalization era. It is because the process of teaching English should be started since the people are in their early age. According to Cameron \& McKay (2010), young learners are defined as a beginner learner at the age of 5-12 years old.

The process of teaching English for young learners should be done by considering some characteristics of young learners. One of those characteristics are stated by Piaget in Cameron (2001) that young learners are an active learner. As an active learner, young learners tend to learn something indirectly by discovering and exploring things through seeing, hearing, touching, and interacting (Hartani, 2012). Thus, an innovative and attractive ways of teaching are needed to make the young learners involved in learning process.

One kind of strategy that can be used in teaching English for young learners is by using a media in the process of teaching and learning. According to Wahyuni (2013), media is something that can be used to deliver information or transfer the material of teaching. Meanwhile, the media also can be used to conduct teaching and learning activities and support students to reach their instructional objectives of lesson (Scanlan in Aini, 2013). In addition, there are some examples of media that can be used by the teacher such as the students themselves, realia, picture, course book, board, OHP, flipchart, and LCD (Harmer as cited in Aini, 2013).

The use of media in learning process had been done by English teacher in teaching sixth grade students of SD Lab UNDIKSHA Singaraja. Based on preliminary research that had been conducted, the used of media gave contribution in learning process such as made the process of learning run effectively, and involved the students in learning process. Furthermore, the kinds of media used were still limited in forms of students themselves, realia, picture, flashcard, course book, board, and LCD. Hence, a new kind of media was needed to be implemented in order to make the process of learning become more innovative.

\footnotetext{
* Corresponding author.

E-mail Addresses: suryamahayanti.sm@gmail.com (Ni Wayan Surya Mahayanti)
} 
Considering the phenomenon above, new kind of media that can be used is a big book. Hall \& O'Connor (2006) stated that big book is a larger format book with big texts and big illustrations. It is considered as one of the most effective way of making the young learners involved in learning process as well as developing their literacy, facilitating them in learning new vocabulary, and enhancing their comprehensions of texts (Rahim \& Harun, 2010). According to Karges-Bone as cited in Hall \& O'Connor (2006), there are some criteria of a successful big book learning experience such as (1) big book is about 10-15 pages that can engages students' interest, (2) big book contains a rhyme pattern that students notice and learn, (3) big book has big pictures which assist in the construction of meaning, (4) big book has repetitive phrase and controlled vocabulary that can help students in learning vocabulary, (5) big book has simple and interesting storyline, and (6) big book contains elements of humor.

Moreover, the use of big book in learning process is also good for character building of young learners (Kiromi, 2015). It is done through the insertion of character education in the story of the big book. According to Kemendiknas as cited in Hadi (2015), there are eighteen values of character education that should be developed during learning process namely (1) religious, (2) honest, (3) tolerant, (4) disciplined, (5) hardworking, (6) creative, (7) independent, (8) democratic, (9) curious, (10) nationalistic, (11) patriotic, (12) appreciative of achievement, (13) friendly/communicative, (14) peace loving, (15) fond of reading, (16) environmental care, (17) social care, and (18) responsible. Those kinds of character education can be inserted in the story of the big book based on the needs of the students to build their character.

The existence of character based big book especially in Buleleng, Bali still not developing yet due to the price of big book which is too expensive. Meanwhile, a development of character based big book should be developed in order to provide a new kind of media for teaching English as well as new source of book which inserting character education. Based on that condition, this research was aimed to develop character based big book that can be used for teaching English at sixth grade students at SD Lab UNDIKSHA Singaraja and find out the quality of the media developed.

\section{Method}

This research was a development research (research and development) that conducted based on research and development model by Sugiyono (2009), in which the procedure of this research was conducted until the seven procedures from ten procedures designed by Sugiyono. This kind of development model was also used by Wardani (2015) who also implemented her research until the seven procedures namely identifying potency and problem, collecting data, designing product, validating design product, revising design product, trying-out product, and revising product. The subject of this research was 32 students of sixth grade students of SD Lab UNDIKSHA Singaraja, while the object of this research was big book in the form of character based big book. The data of this research was analyzed both qualitatively and quantitatively. The qualitative data was gathered from observation sheet, interview guide, item of questionnaire, checklist, and notes, while the quantitative data was obtained from the rubric filled by the expert judges and the teacher's questionnaire during trying-out product.

\section{Findings and Discussion}

The development of character based big book as a media for teaching English at sixth grade students at SD Lab UNDIKSHA Singaraja was done by conducting seven procedures based on research and development model by Sugiyono (2009). The first procedure of developing the media was identifying potency and problem. In this procedure, observation sheet, item of questionnaire, and interview guide were used in order to find out the kinds of media used by the teacher in the process of teaching English at sixth grade students at SD Lab UNDIKSHA Singaraja. Based on the result of observation, it was found that one kind of media that commonly used by the teacher was course book. It was in line with the result of students' questionnaire, in which $93.55 \%$ students said that the most common media used was course book Thus, the researcher conducted a research in developing a new kind of media in the form of character based big book.

The second procedure of this research was collecting data. There were two steps that had been conducted during collecting data namely syllabus analysis and library research. In syllabus analysis, the researcher used checklist that filled by the teacher in order to find out what kind of theme of big book that need to be developed. The checklist was made by the researcher based on the syllabus used for teaching sixth grade students at SD Lab UNDIKSHA Singaraja. Meanwhile, the library research was conducted in order to find some sources related to development of a good character based big book. Based on the result of syllabus analysis, it was found that there were find kinds of theme that need to be developed as character based big 
book. Those themes were seasons, tourism, direction, airport, and transportation. From those kind of themes, character based big book was designed in the form of printed out book.

The next procedure of developing character based big book was designing product. After finding out the themes of big book, the design of the character based big book was developed. In this procedure, the researcher created blueprint of the big book then developed the blueprint into the draft of the big book. In developing the draft of the big book, firstly, the stories were created based on the themes in which the character education also inserted in the stories. Each story had different kind of character education. After creating the story, the illustrations were created as well as the layout of the big book. Thus, there were five kinds of character based big book that had been developed in this procedure. Those big books entitled "Bibbie's Seasons Adventure", "Riry Rabbit's Dream Holiday", "Follow Me", "At the Airport", and "On the Road". The kinds of character education that was inserted in those big book were honest, disciplined, independent, democratic, curious, friendly/ communicative, environmental care, and responsible. Those big books were still printed out in small size (A5). The example of the layout of big book could be seen on table 1

Table 1. The example of the layout of character based big book

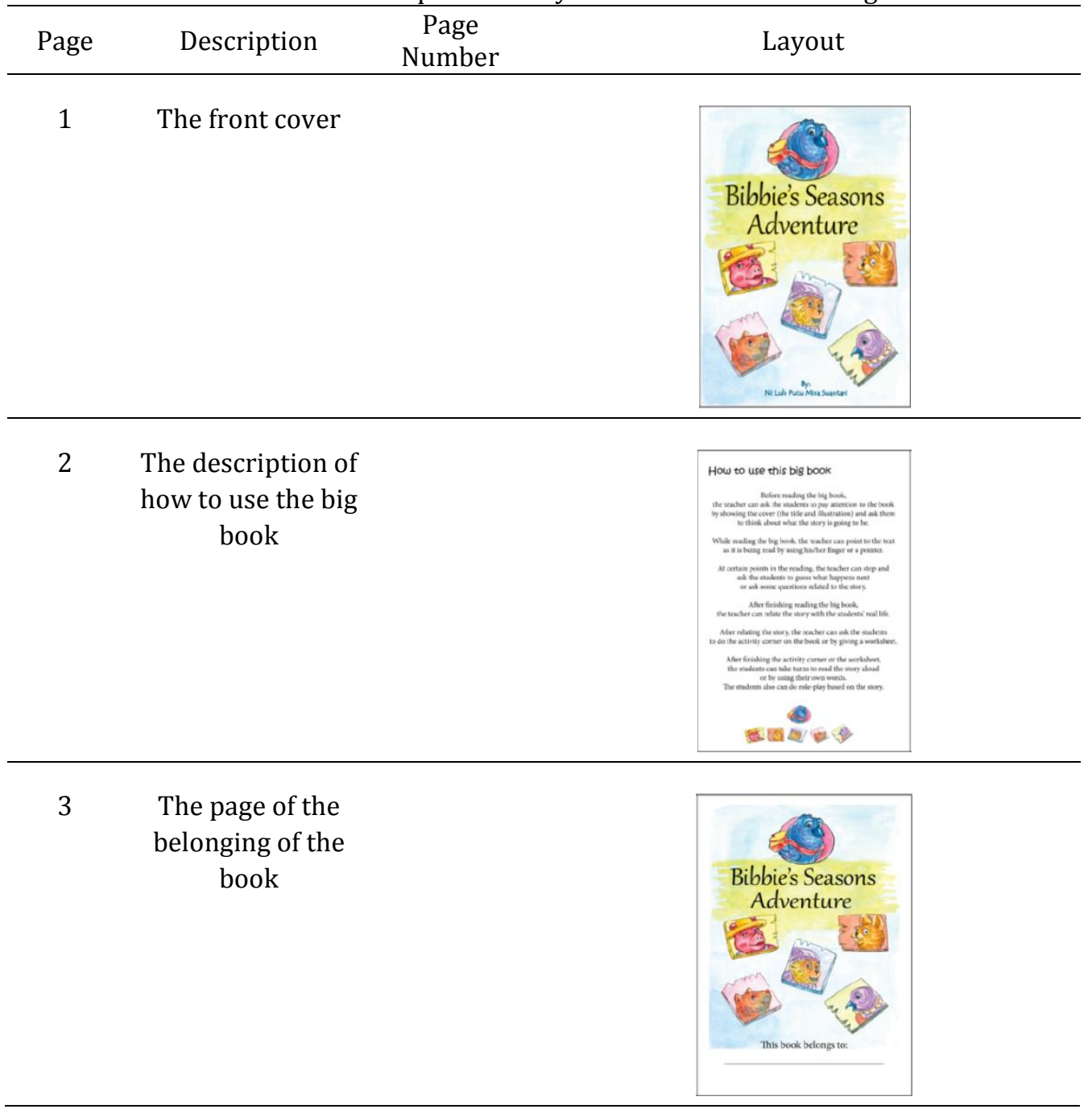




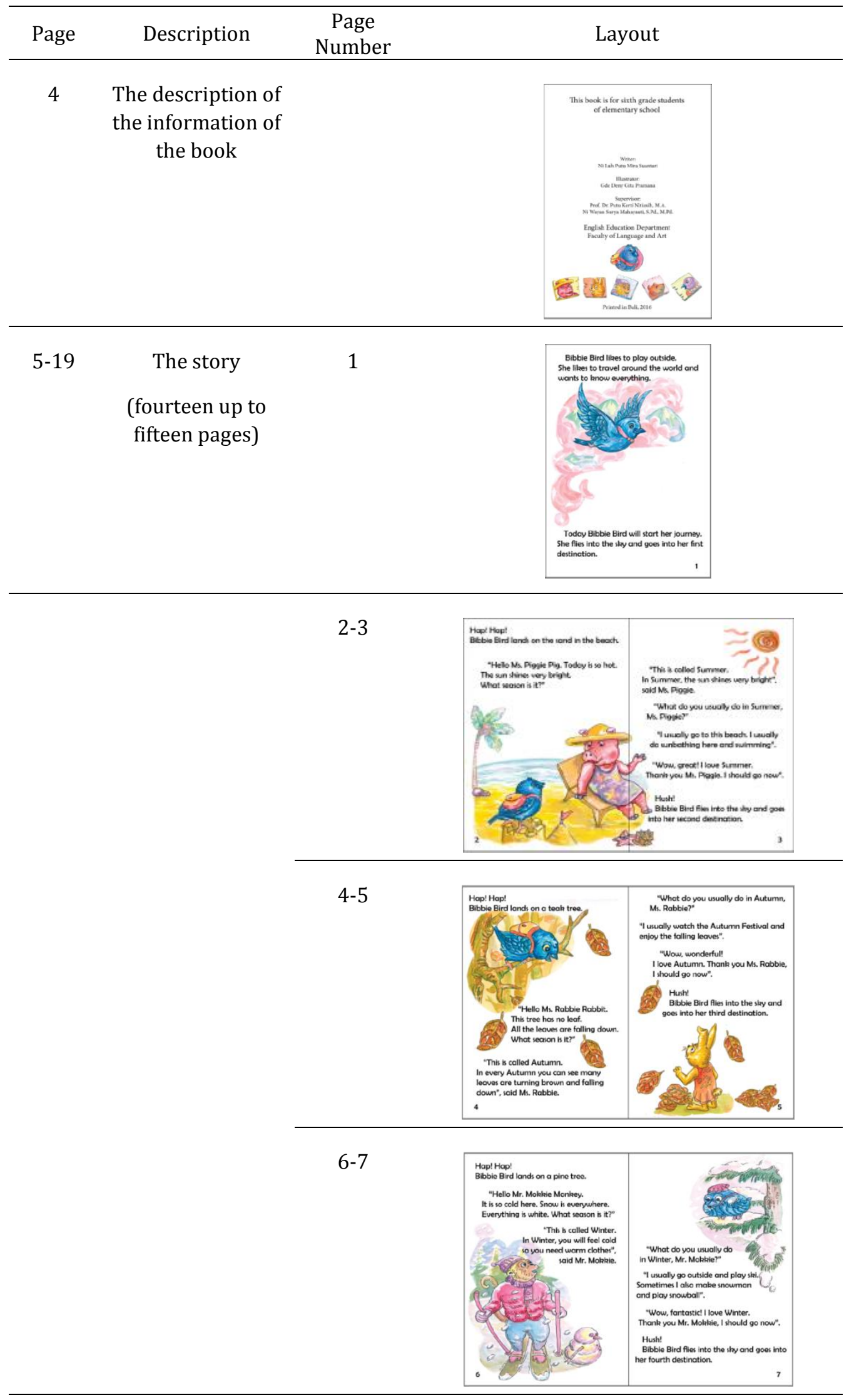




\begin{tabular}{|c|c|c|c|c|}
\hline Page & Description & $\begin{array}{c}\text { Page } \\
\text { Number }\end{array}$ & \multicolumn{2}{|c|}{ Layout } \\
\hline $5-19$ & $\begin{array}{l}\text { The story } \\
\text { (fourteen up to } \\
\text { fifteen pages) }\end{array}$ & $8-9$ & 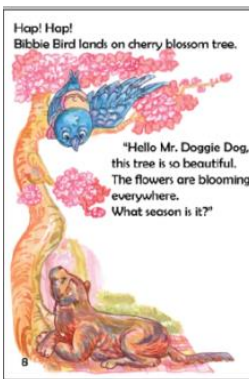 & 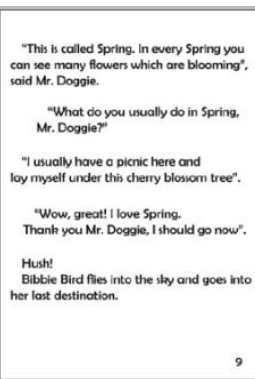 \\
\hline
\end{tabular}
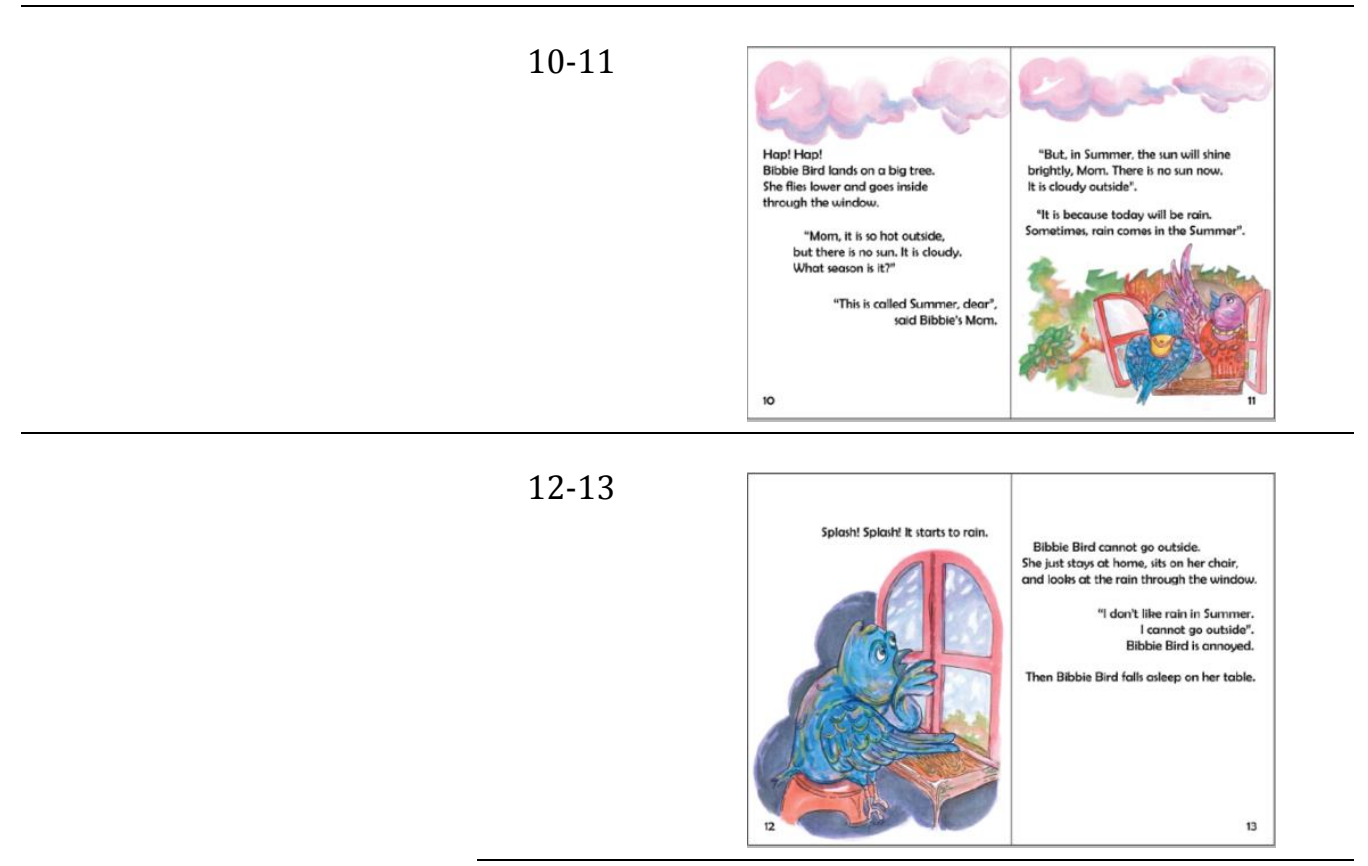

14-15

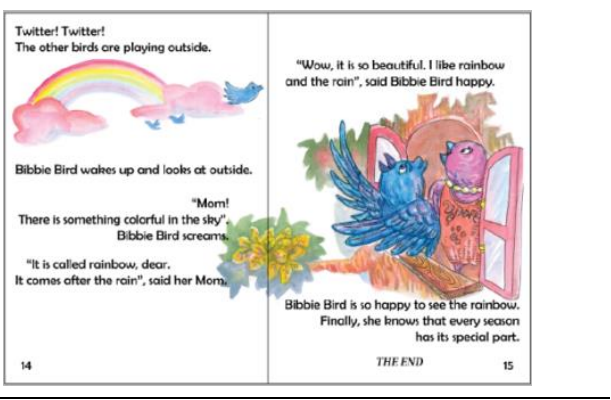

After designing product, validating design product was conducted. Validating design product was done by using two expert judges. The expert judges validated the content of the big book based on the criteria of the theme used in the syllabus, criteria of good big book, and criteria of character education that inserted in the big book. Based on the result of the expert judges, it was found that the character based big book was categorized as good and excellent media.

After validating design product, the next procedure was revising design product. This procedure was conducted in order to make the media of character based big book better before it was used in trying-out. The revisions of design product were done in term of the grammar, context, diction, illustrations, and mechanism.

The sixth procedure of this research was trying-out product. Trying-out product was done at SD Lab UNDIKSHA Singaraja for sixth grade students. It was conducted as an implementation of the use of big book in the classroom. In trying-out product, there were two kinds of data instruments used namely observation sheet, and item of questionnaire for students and teacher. Based on the result of the questionnaire, 53.13\% 
of the students were happy to be taught by using big book. Moreover, it was found that $56.25 \%$ of the students said that the use of big book could help them in learning English and 46.87\% said that big book could motivate them in learning English. In addition, 50\% students said that the quality of big book was very good. Those results of students questionnaire were in accordance with the result of teacher's questionnaire. Based on teacher's questionnaire, it was found that the quality of the big book developed was good. It could be used to make the process of learning especially in reading activity run smoothly. Furthermore, the use of character based big book also could help the teacher to attract students' attention and introduce new vocabulary related to the theme given.

The last procedure of this research was revising product. Based on the result of the previous procedures, there was no revision of the content of the character based big book. The final product of character based big book could be seen on figure 1
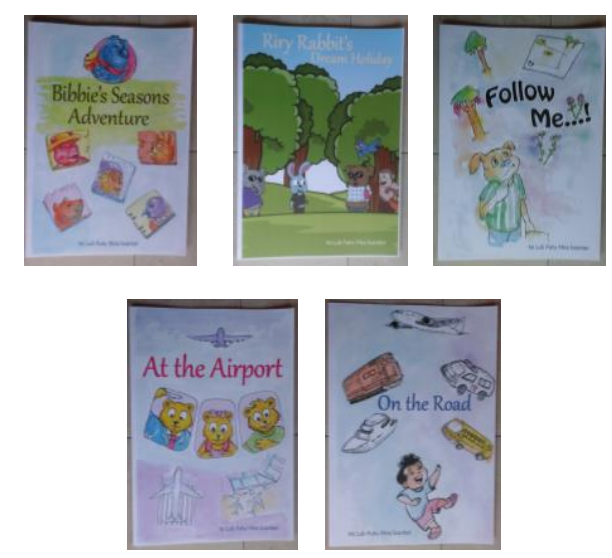

Figure 1. Media of Character Based Big Book

For finding the quality of the character based big book, result of expert judgment and teacher's questionnaire during trying-out product were used. Both of rubric expert judgment and the teacher's questionnaire consisted of three components namely the theme used in the syllabus, the criteria of good big book, and the character education inserted in the big book. Those three components were analyzed by using the formula on table 2

Table 2. Formula Used in Analyzing the Quality of the Big Book Developed

\begin{tabular}{cc}
\hline Score & Criteria \\
\hline $\bar{X} \geq \mathrm{M} i+1.5 \mathrm{Sdi}$ & Excellent Media \\
\hline $\mathrm{M} i+0.5 S d i \leq \bar{X}<\mathrm{M} i+1.5 S d i$ & Good Media \\
\hline $\mathrm{M} i-0.5 S d i \leq \bar{X}<\mathrm{M} i+0.5 \mathrm{Sdi}$ & Average Media \\
\hline $\mathrm{M} i-1.5 S d i \leq \bar{X}<\mathrm{M} i-0.5 \mathrm{Sdi}$ & Below Average Media \\
\hline $\bar{X}<\mathrm{M} i-1.5 \mathrm{Sdi}$ & Poor Media \\
\hline (Nurkancana \& Sunartana in Mahayanti, 2011)
\end{tabular}

Based on those three components in analyzing the quality of the big book, it was found that the total of maximum score was 165 and the total of minimum score was 33. From those score, the result of Mi and Sd $i$ were found that was 99 for Mi and 33 for Sdi. After finding the result of Mi and Sdi, the result of criteria on table 2 should be found by inputting the result of M $i$ and Sdi. Thus, the result of the criteria on table 2 was described on table 3 
Table 3. Result of the Formula in Analyzing the Quality of Big Book Developed

\begin{tabular}{cc}
\hline Score & Criteria \\
\hline $\bar{X} \geq 148.5$ & Excellent Media \\
\hline $115.5 \leq \bar{X}<148.5$ & Good Media \\
\hline $82.5 \leq \bar{X}<115.5$ & Average Media \\
\hline $49.5 \leq \bar{X}<82.5$ & Below Average Media \\
\hline $\bar{X}<49.5$ & Poor Media \\
\hline
\end{tabular}

From the result of the first and the second expert judges, it was found that the total score of all components was 147 and 157. Based on those score, the character based big book was categorized as good and excellent media. Those results were in line with the result of teacher's questionnaire during trying-out product. The total score of all components based on the teacher's questionnaire was 153 which belonged to excellent media. Thus, it could be concluded that the quality of the media was categorized as excellent media.

\section{Discussion}

The kind of character based big book developed in this research was the character based big book which was based on three criteria. Those criteria were the theme in the syllabus used at SD Lab UNDIKSHA Singaraja, the criteria of good big book, and the kinds of character education inserted in the story in the big book. Those kinds of character based big books were developed by conducting seven procedures based on Sugiyono model.

Based on the identifying potency and problem, it was found that $93.55 \%$ students said that course book was used very often in the classroom during teaching and learning process. Course book was effective to be used, but it was less attractive. It failed to present appropriate and realistic language models, and failed to contextualize language activities (Richards and Renandya in Kayapinar, 2009). Therefore, a new kind of media in the form of big book needed to be developed in order to bring an innovation in the process of teaching English and create fun learning activity. According to Strickland \& Morrow in Nambiar (1991), big book was an enlarge version of children's book which considered as the most effective way to make the young children involved in learning process. In addition, the use of media in form of big book could facilitate students' comprehension of a story and encourage them to read (Rahim \& Harun, 2010).

Designing the product of media big book was done after conducted syllabus analysis and library research. Based on the syllabus analysis filled by the teacher, there were five kinds of theme that needed to be developed as character based big book such as seasons, tourism, direction, airport, and transportation. The type of character based big book that was developed was in the form of print out book of character based big book.

After decide the type and the theme of big book, the character based big book was developed by designing the story, inserting the character education, creating illustrations, and creating layout of the big book. In creating the story of big book, the big book developed consisted of 14-15 pages and had interesting storyline. It was in accordance with Karges-Bone as cited in Hall \& O'Connor (2006) who stated that the criteria of good big book was consisted of 10-15 pages. The illustrations of the big book developed were also big and visible to the entire class (Hall \& O'Connor, 2006). The big book developed also consisted of character education that could be learnt by the students through reading the story in the big book. The kinds of character education inserted were honest, disciplined, independent, democratic, curious, friendly/communicative, environmental care, and responsible. Those kinds of character education was in line with eighteen values that should be developed during learning process by Kemendiknas as cited in Hadi (2015) such as (1) religious, (2) honest, (3) tolerant, (4) disciplined, (5) hardworking, (6) creative, (7) independent, (8) democratic, (9) curious, (10) nationalistic, (11) patriotic, (12) appreciative of achievement, (13) friendly/communicative, (14) peace loving, (15) fond of reading, (16) environmental care, (17) social care, and (18) responsible.

After designing the product, the character based big book had validated by the expert judges by using rubric consisted of three components. Those components were the theme used in the syllabus of sixth grade students at SD Lab UNDIKSHA Singaraja, the criteria of good big book proposed by KargesBone as cited in Hall \& O'Connor (2006), and the kinds of character education based on Kemendiknas as 
cited in Hadi (2015). The result of the expert judgment as well as the comments and suggestions were used in revising the product and minimized the weaknesses of the big book developed.

The process of trying-out the product was conducted after revising design product. From the result of students' questionnaire during trying-out product, it was found that $53.13 \%$ of the students were happy to be taught by using big book. Moreover, most of them also said that big book was helpful and made them motivated in learning English. It was in line with the function of big book in building fun and meaningful experience for the students and the teacher (Hall \& O'Connor, 2006).

Therefore, based on result of the data obtained from the expert judgment and teacher's questionnaire during trying-out, it could be concluded that the quality of the big book developed was categorized as excellent media. The character based big book developed had consisted all criteria of good big book. Thus, it was proper to be used as a media in teaching English because it could offer a new way to develop literacy, facilitate the learning of new vocabulary, and enhance comprehension of texts (Rahim \& Harun, 2010).

However, this research was far from perfection. Besides some strengths of the media developed, there were still some weaknesses that need to be minimized in the form of the implementation of the big book in the classroom. The use of big book was less effective to be used in a big class which consisted of more than thirty students. Thus, it would be more effective if the implementation of the big book was done by dividing students into small group consisted of five up to ten students.

\section{Conclusion}

From the data analysis, it can be concluded that there were five kinds of character based big book that was developed as a media for teaching English at six grade students at SD Lab UNDIKSHA Singaraja. Those big books were the big book which based on the theme in the syllabus used, based on criteria of good big book, and consisted of character education. The themes of the big book developed were seasons, tourism, direction, airport, and transportation. Those big books had big size as well as big texts and illustration. The size was about 11 to 17 inches tall (A3) in which each big book was consisted of fourteen up to fifteen pages. Moreover, the big books developed had simple and interesting storyline. It also consisted of character education that could be learnt by the students during reading the story of the big book. The kinds of character education inserted in the story were honest, disciplined, independent, democratic, curious, friendly/communicative, environmental care, and responsible.

Therefore, based on the result of expert judgment and teacher's questionnaire during trying-out product, it was found that the quality of the big book was categorized as excellent. Thus, it means that character based big book is proper to be used as a media for teaching English at sixth grade students at SD Lab UNDIKSHA Singaraja.

\section{Reference}

Aini, W. N. (2013). Instructional media in teaching English to young learners: a case study in elementary schools in Kuningan. Journal of English and Education 1(1), 196-205. Retrieved from http://ejournal.upi.edu/index.php/L-E/article/viewFile/350/239

Cameron, L. (2001). Teaching languages to young learners. United Kingdom: Cambridge University Press

Cameron, L., \& McKay, P. (2010). Bringing creative teaching into the young learner classroom. New York: Oxford University Press.

Hadi, R. (2015). The integration of character values in the teaching of economics: a case of selected high schools in Banjarmasin. International Education Studies 8(7), 11-20. Retrieved from http://files.eric.ed.gov/fulltext/EJ1070736.pdf

Hall, S.C. \& O'Connor, B. (2006). Using big books: a standards-based instructional approach for foreign language teacher candidates in a preK-12 program. Journal of Foreign Language Annals 39(3), 487506. Retrieved from http://web.pdx.edu/ fischerw/courses/advanced/ methods_docs/pdf_doc/wbf_collection/0401_0450/0407_FLA_2006_Colville_BigBooks.pdf

Hartani, A. L. (2012). The effectiveness of mime game in teaching English Grammar. TEYLIN 2, 15 -21. Retrieved from http://eprints.umk.ac.id/340/4/PROCEEDING_TEYLIN_2.21-27.pdf

Kayapinar, U. (2009). Coursebook evaluation by English teachers. Inonu Univarsity Journal of the Faculty of $\begin{array}{llll}\text { Education } & \text { 10(1), 69-78. } & \text { Retrieved }\end{array}$ http://dergipark.ulakbim.gov.tr/inuefd/article/download/5000004220/5000004733

Kiromi, I. H. (2015). Pengembangan media pembelajaran melalui big book untuk pembentukan karakter anak usia dini. Retrieved from http://eprints.uny.ac.id/27139/1/abstrak-ivonne-hafidlatikiromi.pdf 
Mahayanti, N. W. S. (2011). Developing media for group work activity in teaching reading for fifth grade students of elementary school in Buleleng district in the academic year 2010/2011 (Unpublished thesis). Universitas Pendidikan Ganesha, Singaraja.

Nambiar, M.K. (1991). Big books for little readers: works in the ESL classroom too. Retrieved from http://files.eric.ed.gov/fulltext/ED333736.pdf

Rahim, N. A., \& Harun, N. I. (2010). Students' perception towards the usage of the big book. Gading Business and Management Journal 14, 49-54. Retrieved from http://www2.pahang.uitm.edu.my/upena/docs/5_Students\%E2\%80\%99\%20Perception\%20Tow ards\%20The\%20Usage\%20of\%20the\%20Big\%20Book\%20ana.pdf

Sugiyono. (2009). Metode Penelitian Pendidikan (Pendekatan Kuantitatif, Kualitatif, dan R\&D). Bandung: Alfabeta

Wahyuni, T. (2013). The effectiveness of using picture series as media in teaching speaking of the first grade students of SMAN 1 Kampak. Retrieved from http://repo.iaintulungagung.ac.id/574/5/CHAPTER\%20II.pdf

Wardani, K. Y. (2015). Pengembangan lembar kegiatan siswa (LKS) Fisika berbasis inquiry learning pada pokok bahasan gerak lurus SMA kelas X semester I. JRKPF UAD 2(1), 25-28. Retrieved from http://journal.uad.ac.id/index.php/JRKPF/article/viewFile/3132/pdf_8 